\title{
Financial Sector Reforms and Economic Growth in Ghana: a Dynamic ARDL Model
}

\author{
Erasmus L. Owusu', Nicholas M. Odhiambo²
}

ABSTRACT

\begin{abstract}
This paper examines the relationship between financial sector reforms and sustainable economic growth in Ghana. Employing the autoregressive distributed lag (ARDL) bounds testing approach and using GDP per capita as a growth indicator, this paper establishes a long-run relationship between economic growth and financial reforms, which is represented by an index calculated using principal component analysis (PCA). The paper finds that in the long run, financial sector reforms have an insignificant impact on economic growth in Ghana. This supports numerous past studies that have reported mixed or inconclusive results on the effects of financial reforms on economic growth. The paper concludes that increase in capital stock, not financial sector policy reforms, affects economic growth in Ghana. This paper therefore recommends an increase and modernization of capital stock in order to promote real sector growth in Ghana.
\end{abstract}

KEY WORDS: $\quad$ Africa; Ghana; Economic Growth; Financial Sector Reforms; ARDL Bounds Testing Approach

JEL Classification: $\quad$ C32; G12; 016; O47

${ }^{1}$ AC Nielsen - Data Science, Oxford, United Kingdom; ${ }^{2}$ University of South Africa, Pretoria, South Africa

\section{Introduction}

The purpose of this paper is to empirically investigate and provide insight into the impact of financial liberalization on sustainable economic growth in Ghana (a member of the Economic Community of West African States - ECOWAS). ECOWAS is made up of 15 countries in the West African sub-region, namely, Benin, Burkina Faso, Cape Verde, Ivory Coast, Gambia, Ghana, Guinea-Bissau, Guinea, Liberia, Mali, Niger, Nigeria, Senegal, Sierra Leone and Togo. This paper constructs a financial liberalization index factor [This $\underline{-1}$ factor will be used instead of dummies to represent the

Correspondence concerning this article should be addressed to: Erasmus L. Owusu. E-mail: erasmus.owusu@talk21.com

This paper is based on the author's doctoral research at the University of South Africa (UNISA). The usual disclaimer applies. effect of financial sector reforms in Ghana. A similar approach was employed by Caprio, Honohan and Stiglitz (2001) and Laeven (2003)], taking into account all the relevant policies of financial liberalization used in Ghana using principal component analysis (PCA). The paper uses the Phillips and Peron (1988) unit root test and the Dickey-Fuller Generalized Least Squares (DF_ GLS) in order to test for the stationarity of the variables. The paper then applies the empirical analytical ARDL Bounds testing approach in order to establish a longterm relationship between financial liberalization and sustainable economic growth using time-series data. Lastly, a dynamic unrestricted error-correction model (UECM) is derived from the ARDL Bounds testing model to analyze the existing short-run relationship. The sources of the data include various issues of the World Bank's World Development Report (2009a), the World Bank's African Development Indicators (2009b), 
the IMF's International Financial Statistics, the Bank of Ghana, Ghana Statistical Services and other relevant sources.

This paper contributes to the literature on financial liberalization by establishing whether financial sector reforms have a positive influence on economic growth in Ghana. The paper uses time series data from 1969 to 2008 , covering periods of both financial repression and financial liberalization. However, the main period of this paper is the post-liberalization period. The motivation for using financial liberalization index factors is to ensure that all the various financial sector reforms implemented in the attainment of full financial liberalization status are taken into account for Ghana and to help solve the problem of the quantification of the effect of financial liberalization, which is one of the problems often associated with empirical studies in this area (Caprio et al., 2001; Laeven, 2003).

In addition, most recent studies published on financial reforms and economic growth are based on evidence mainly from South American and the East Asian countries, with little or no attention devoted to African countries, especially countries in the ECOWAS region. The potential weakness of this paper is that the application of the findings to any other country should come with a proviso. Additionally, we did not apply Bartlett's test for sphericity to the financial liberalization index, and we did not obtained its KaiserMayer-Olkin (KMO) coefficient. We therefore recommend that future studies apply this test to see if they reach the same conclusion.

This paper is divided into six sections, including the introduction. In section two, the paper reviews financial sector reforms in Ghana. This is followed in section three by the literature review, both theoretical and empirical. In section four, the paper looks at the methodology and the empirical analysis. The conclusion is elaborated in section five, followed by the references.

\section{An overview of financial Sector Reforms in Ghana}

From its independence in 1957 to the year 1983, Ghana pursued a growth strategy policy, which can only be described as a policy based on inward-oriented trade, led by the public sector, and aimed at the achievement of social welfare objectives (Aryeetey, 1994). As a result, the budgetary pressures and the fast-depleting external reserves that led to shortages in the Ghanaian economy in the 1960s forced the introduction of price-control policies for the administrative allocation of scarce goods and services.

These policies extended to the financial services as well. By the mid-1960s, the price control regime became official with the establishment of a Price and Income Board. In the financial sector, banks were forced to provide credit on the basis of social and political considerations, and they were obliged to make sure that these credits were channeled into priority sectors, such as agriculture. In order to cope with the cost of credit, exchange rates and interest rates were fixed by the government.

The price-control regime instigated distortions in the market that led to the misallocation of resources. Economic growth rates declined as a result of price distortions, which affected the production of the real sector in the economy. The control of the foreign exchange market led to the over-valuation of the domestic currency and therefore weakened the export sector at the expense of an increased appetite for foreign goods, which worsened the balance of payments. According to Sowa and Acquaye (1999), the control of interest rates together with the high rate of inflation brought about a system of financial repression, which weakened the development of the financial sector and subjected the allocation of credit to political patronage.

An integral part of this inward-oriented policy strategy was the control that the government had over the financial sector. There were interest rate ceilings - both on deposits and credits - and there was no stock market. Government policies favored the mobilization of savings and the allocation of credits through government-owned financial institutions (Bank of Ghana, 2009). Despite this policy favoritism, domestic savings mobilization by the banks was unsatisfactory. For instance, between 1969 and 1986, financial deepening in Ghana, as measured by the ratio of M2 to GDP, averaged $17.3 \%$. This poor performance could be attributed to: (i) citizens' lack of confidence in the financial sector during that period; (ii) low deposit interest rates (fixed by the government); and (iii) the emergence of the large-scale migration of Ghanaian workers - especially to Nigeria and Libya for "greener pastures." 

deposits are substitutes for cash or gold, rather than loans extended to the informal sector.

Stiglitz (1989) also criticized the policy of financial liberalization on the theoretical ground of market failures in financial markets. Neo-structuralists argued that high interest rates increase inflation in the short run through cost-push effects and decelerate economic growth as a result of the reduced real credit volume. These theoretical considerations are, however, complemented by policy requirements in developing countries where, if the government is unable to collect sufficient tax revenue, it imposes financial repressive measures as an implicit tax on the financial sector (Fry, 1995).

Fry (1995) stated that financial repression is a severe and unintended form of financial restriction, which he considered to be a second-best policy for governments with low tax-raising powers. Reserve requirements, obligatory holdings of government bonds, or interest rate ceilings help authorities to divert savings to the public sector at low or zero costs.

\subsection{Empirical Evidence}

Research findings based on the McKinnon-Shaw hypothesis have rather mixed results. Additionally, available evidence shows that in addition to macroeconomic stabilization, sound and proven regulation of the financial sector seems to play a significant and important role in the successful implementation of interest rate reform policy in developing countries.

Berthélemy and Varoudakis (1995) explored the relationship between financial liberalization and economic growth. They based their analysis on convergence club tests, which help to check for any potential poverty traps. They used sample data from 91 countries in the 1960-1985 period. They concluded that educational attainment is a priority factor with respect to economic development but that financial factors such as interest rate liberalization could lead to high or low economic growth outcomes.

In other words, convergence groups with similar long-run economic growth rates have the same impact as financial liberalization. These authors also showed that inadequate financial conditions may severely limit economic growth in countries that already have a sufficient stock of human capital to begin the process of economic development. They concluded that this indicates the existence of poverty traps.
In another study, Levine and Zervos (1998) used cross-sectional data from 47 countries for the period from 1976 to 1993 in order to investigate the impact of stock market activity on economic growth, capital stock growth, productivity growth, and the private savings rate. They reported a strong positive relationship between stock market liquidity (as measured by initial value traded as a ratio of GDP plus the initial turnover ratio - i.e., value traded as a ratio of average market capitalization), real GDP growth, capital stock growth and productivity growth.

They also found that other financial variables, such as stock market size, volatility and integration into international capital markets were not necessarily strongly linked to economic growth. Furthermore, using stock market liquidity and financial deepening (as measured by bank credits to the private sector as a ratio of GDP) in their model, they simultaneously showed a positive relationship with economic growth. They argued that this is an indication that banks and stock markets provide different financial services in an economy. Adu et al. (2013) investigated the longrun growth effects of financial development in Ghana. They used indices created from principal component analysis (PCA) and confirmed that the impact of financial development on economic growth in Ghana depends on the indicator used to proxy financial development.

\section{Methodology and Empirical Analysis}

\subsection{Methodology}

According to the McKinnon and Shaw hypothesis and neo-classical economists, financial liberalization is expected to ultimately lead to an increase in economic growth. Based on this assumption, this paper specifies a model designed to evaluate the impact of financial liberalization on the macro-economic developments. This paper uses Beck et al. (2000) and specifies a modified model for real GDP per capita, a measure of economic growth, as a function of government expenditure, inflation and the financial liberalization index, as well as variables for labor and capital formation as

$$
\begin{aligned}
& \operatorname{In} Y_{t}=C_{t}+\mathrm{aIn} K_{t}+\mathrm{bIn} L_{t}+\mathrm{q} \operatorname{In} G E X P_{t}+\mathrm{pIn} I N F L_{t}+ \\
& +\mathrm{w} F L B L_{t}+\mathrm{e}_{t}
\end{aligned}
$$



this stage, the testing involves the estimation of the long-run coefficients (which represent the optimum order of the variables after selection by AIC or SBC) and then calculating the associated error correction model in order to establish the adjustment coefficients of the error correction term (Masih et al., 2008). The short-run effects are therefore captured by the coefficients of the first-differenced variables in the UECM model. According to Bahmani-Oskooee and Brooks (1999), the existence of a long-term relationship is established from Equation (1), but this does not necessarily mean that the estimated coefficients are stable.

There is, however, the need to perform a series of test diagnoses on the model established. This involves testing the residuals (i.e., homoscedasticity, non-serial correlation, etc.), as well as stability tests to ensure that the estimated model is statistically robust.

The unrestricted error correction model (UECM) of equation (1) is estimated as follows:

$$
\begin{aligned}
& \Delta \operatorname{In} Y_{t}=\mathrm{c}_{0}+\delta_{1} \operatorname{In} Y_{t-1}+\delta_{2} \operatorname{In} K_{t-1}+\delta_{3} \operatorname{In} L_{t-1}+\delta_{4} \operatorname{InGEXP_{t-1}+} \\
& +\delta_{5} \operatorname{In} I N F L_{t-1}+\delta_{6} F L B L_{t-1}+\sum_{i=1}^{p} \alpha_{\mathrm{i}} \Delta \operatorname{In} Y_{t-1}+\sum_{i=0}^{q} \beta_{\mathrm{j}} \Delta \operatorname{In} K_{t-j}+ \\
& +\sum_{i=0}^{q} \gamma_{1} \Delta \operatorname{In} L_{t-l}+\sum_{i=0}^{q} \lambda_{\mathrm{r}} \Delta \operatorname{In} G E X P_{t-r}+\sum_{i=0}^{q} \theta_{\mathrm{p}} \Delta \operatorname{In} I N F L_{t-p}+ \\
& +\sum_{i=0}^{q} \phi_{z} \Delta F L B L_{t-z}+\mathrm{e}_{t}
\end{aligned}
$$

Where: i) the coefficients $\alpha_{i}, \beta_{j}, \gamma_{1}, \lambda_{r}$, and $\theta_{p}$ represent the short-run dynamics of the model; ii) the coefficients $\delta \mathrm{i}$ represent the long-run multipliers corresponding to long-run relationships; iii) $\mathrm{c}_{0}$ is the drift; and iv) $e_{t}$ is the white noise error term.

\subsection{Empirical Analysis}

\subsubsection{Unit root tests for variables}

As indicated in section one, the results of the DickeyFuller generalized least squares (DF-GLS) and the Phillips and Peron (PP) unit root tests for the variables used are shown in Tables 1a, 1b, 2a and 2b. The DFGLS lag length is selected automatically by AIC, while the PP truncation lag is selected automatically on the Newey-West bandwidth.

The results from Tables $1 \mathrm{a}, 1 \mathrm{~b}, 2 \mathrm{a}$ and $2 \mathrm{~b}$ show that all the variables are either $\mathrm{I}(0)$ or $\mathrm{I}(1)$ using both unit root tests. The null hypothesis that the variables have unit roots on the basis of Akaike Information Criteria (AIC) and on the Newey-West bandwidth are therefore rejected.

\subsubsection{Co-integration Analysis: ARDL bounds Test}

The results of the co-integration test based on the ARDL bounds testing approach are reported in Table 3.

Thus, the null hypothesis of the non-existence of co-integration among the variables is rejected. This implies that there is a long-run co-integration relationship among the variables when the model is normalized on real GDP per capita (InRGDP) in Ghana. The long-run results of the selected model are reported in Table 4 below.

The results reported in Table 4 show that the coefficient of the real government expenditure (InGEXP) is statistically insignificant and has an unexpected a priori sign. The coefficient of inflation (InINFL) is statistically significant at the $5 \%$ level, and it has the expected negative sign. Furthermore, the coefficient of the combined financial Sector Reform index (FLBL), which serves as the proxy for the changes and implementation of the policy, has the expected sign but is statistically insignificant. Thus, financial sector reforms in Ghana have insignificant impact on economic growth in the long run.

However, capital accumulation (InK) has the expected sign and is statistically significant at the $5 \%$ level. Thus, a $1 \%$ increase in capital accumulation leads to an increase of approximately $0.9 \%$ in economic growth in the long run. The short-run dynamics of the model are shown in Table 5.

The coefficients of $\Delta \mathrm{InRGDP}_{-1,} \Delta \mathrm{InK}, \Delta \mathrm{LnK}_{-1}$ and $\triangle$ InINFL are all statistically significant at the $10 \%$ level. However, the coefficients of $\triangle \mathrm{InL}, \triangle \mathrm{InGEXP}$ and $\triangle F L B L$ are all statistically insignificant. The coefficient of $\operatorname{ECM}(-1)$ is found to be statistically significant at the $5 \%$ level, with the expected negative sign. This confirms the existence of a long-run relationship between the variables. The coefficient of the $\operatorname{ECM}(-1)$ term is -0.22 , which suggests a relatively slow rate of adjustment.

The magnitude of the coefficient of the $\operatorname{ECM}(-1)$ term implies that the disequilibrium occurring due to a shock is totally corrected in approximately 4 years and 7 months at a rate of $22 \%$ per annum. 
Table 1a. DF-GLS unit root tests for variables in levels

\begin{tabular}{|c|c|c|c|c|}
\hline Variable & No Trend & Result & Trend & Result \\
\hline$F L B L$ & 0.920 & $\mathrm{~N}$ & -1.781 & $\mathrm{~N}$ \\
\hline InGEXP & -1.784 & $\mathrm{~N}$ & -2.818 & $\mathrm{~N}$ \\
\hline $\ln I N F L$ & -2.119 & $N$ & -2.478 & $\mathrm{~N}$ \\
\hline $\ln K$ & -0.333 & $\mathrm{~N}$ & -2.079 & $\mathrm{~N}$ \\
\hline $\ln L$ & -0.738 & $\mathrm{~N}$ & -2.352 & $\mathrm{~N}$ \\
\hline $\ln R G D P$ & -1.293 & N & -1.152 & $\mathrm{~N}$ \\
\hline
\end{tabular}

Note: ${ }^{*},{ }^{* *}$ and ${ }^{* * *}$ denote the rejection of the null hypothesis at $10 \%, 5 \%$ and $1 \%$ significance levels, respectively. S= Stationary and $\mathrm{N}=$ Non-stationary. In is the natural log operator. The log of one plus the rate of inflation was used to diminish the impact of some outlier observations.

Table 1b. PP unit root tests for variables in levels

\begin{tabular}{|c|c|c|c|c|}
\hline Variable & No Trend & Result & Trend & Result \\
\hline$F L B L$ & 0.154 & $\mathrm{~N}$ & -2.222 & $\mathrm{~N}$ \\
\hline InGEXP & -2.379 & N & -2.312 & N \\
\hline InINFL & $-3.784^{* * *}$ & $S$ & $-3.947^{* *}$ & $S$ \\
\hline $\ln K$ & -0.559 & $\mathrm{~N}$ & -1.798 & $\mathrm{~N}$ \\
\hline $\ln L$ & -0.796 & $\mathrm{~N}$ & -2.308 & $\mathrm{~N}$ \\
\hline $\ln R G D P$ & -0.567 & $\mathrm{~N}$ & -0.395 & $\mathrm{~N}$ \\
\hline
\end{tabular}

Note: ${ }^{*}{ }^{* *}$ and ${ }^{* * *}$ denote the rejection of the null hypothesis at $10 \%, 5 \%$ and $1 \%$ significance levels, respectively. $S=$ Stationary and $\mathrm{N}=$ Non-stationary. In is the natural log operator. The log of one plus the rate of inflation was used to diminish the impact of some outlier observations.

Table 2a. DF-GLS unit root tests for variables in first differences

\begin{tabular}{|c|c|c|c|c|}
\hline Variable & No Trend & Result & Trend & Result \\
\hline$\triangle F L B L$ & $-5.526^{* * *}$ & S & $-5.814^{* * *}$ & $S$ \\
\hline$\triangle n G E X P$ & $-4.419^{* * *}$ & S & $-5.093^{* * *}$ & $S$ \\
\hline$\triangle n I N F L$ & $-5.925^{* * *}$ & S & $-10.345^{* * *}$ & $S$ \\
\hline$\Delta n K$ & $-7.291^{* * *}$ & S & $-7.927^{* * *}$ & $S$ \\
\hline$\Delta n L$ & $-6.834^{* * *}$ & S & $-6.865^{* * *}$ & $S$ \\
\hline$\triangle n R G D P$ & $-4.400^{* * *}$ & S & $-4.480^{* * *}$ & $S$ \\
\hline
\end{tabular}

Note: $S=$ Stationary and $\mathrm{N}=$ Non-stationary. $\triangle$ is the difference operator, and $\mathrm{In}$ is the natural log operator. ${ }^{*},{ }^{* *}$ and ${ }^{* * *}$ denote the rejection of the null hypothesis at $10 \%, 5 \%$ and $1 \%$ significance levels, respectively. 
Table $\mathbf{2 b}$. PP unit root tests for the variables in first differences

\begin{tabular}{|c|c|c|c|c|}
\hline Variable & No Trend & Result & Trend & Result \\
\hline$\triangle F L B L$ & $-5.688^{* * *}$ & $S$ & $-5.671^{* * *}$ & $S$ \\
\hline$\Delta n G E X P$ & $-4.236^{* * *}$ & S & $-4.229^{* * *}$ & S \\
\hline$\Delta n K$ & $-8.102^{* * *}$ & S & $-8.305^{* * *}$ & $S$ \\
\hline$\Delta n L$ & $-6.744^{* * *}$ & $S$ & $-6.693^{* * *}$ & $S$ \\
\hline$\triangle n R G D P$ & $-4.382^{* * *}$ & S & $-6.178^{* * *}$ & S \\
\hline
\end{tabular}

Note: $\mathrm{S}=$ Stationary and $\mathrm{N}=$ Non-stationary. $\Delta$ is the difference operator, and $\mathrm{In}$ is the natural log operator. ${ }^{*},{ }^{* *}$ and ${ }^{* * *}$ denote the rejection of the null hypothesis at 10\%, $5 \%$ and $1 \%$ significance levels, respectively.

Table 3. Economic Growth and financial liberalization - Bounds F-test for co-integration

\begin{tabular}{|c|c|c|c|c|c|c|}
\hline Dependent variable & \multicolumn{4}{|c|}{ Function } & \multicolumn{2}{|c|}{ F-test statistics } \\
\hline $\ln Y=\ln R G D P$ & \multicolumn{4}{|c|}{$\mathrm{F}_{\operatorname{InY}}(\operatorname{InY} \mid \operatorname{InL}, \operatorname{InK}, \operatorname{InGEXP}, \operatorname{InINFL}, \mathrm{FLBL})$} & \multicolumn{2}{|c|}{$3.769^{* *}$} \\
\hline \multicolumn{7}{|c|}{ Asymptotic Critical Values } \\
\hline et al (2001) & \multicolumn{2}{|c|}{$1 \%$} & \multicolumn{2}{|c|}{$5 \%$} & \multicolumn{2}{|c|}{$10 \%$} \\
\hline p.301, Table Cl(iv) & $\mid(0)$ & $\mid(1)$ & $\mid(0)$ & $\mathrm{I}(1)$ & $\mathrm{I}(0)$ & $\mathrm{I}(0)$ \\
\hline Case IV & 3.50 & 4.63 & 2.81 & 3.76 & 2.49 & 3.38 \\
\hline
\end{tabular}

Note: ** denotes statistical significance at the $5 \%$ level.

Table 4. Economic Growth and financial Reforms - Results of the $\operatorname{ARDL}(2,2,0,0,1,1)$ long-run model selected on the basis of AIC

\begin{tabular}{|c|c|c|c|c|}
\hline Regressor & Co-efficient & Standard Error & T-Ratio & Prob. \\
\hline C & 8.416 & 6.543 & 1.501 & 0.111 \\
\hline InK & 0.899 & 0.701 & 2.273 & 0.041 \\
\hline $\ln L$ & -0.873 & 1.593 & -0.659 & 0.630 \\
\hline $\ln G E X P$ & 0.422 & 0.151 & 1.250 & 0.141 \\
\hline InINFL & -1.242 & 0.556 & -1.809 & 0.050 \\
\hline$F L B L$ & 0.155 & 0.691 & 0.907 & 0.203 \\
\hline
\end{tabular}

Note: Dependent variable: $\ln Y=\ln R G D P$. 
Table 5. Economic Growth and financial Reforms - Results of the ARDL $(2,2,0,0,1,1)$ ECM model selected on the basis of AIC

\begin{tabular}{|c|c|c|c|c|c|}
\hline Regressor & Co-efficient & Standard Error & T-Ratio & & Prob. \\
\hline$\triangle n R G D P_{-1}$ & 0.259 & 0.179 & 1.882 & & 0.066 \\
\hline$\Delta n K$ & 0.089 & 0.057 & 2.233 & & 0.041 \\
\hline$\Delta n K_{-1}$ & -0.134 & 0.026 & -3.861 & & 0.001 \\
\hline$\Delta n L$ & -0.269 & 0.239 & -0.859 & & 0.456 \\
\hline$\triangle n G E X P$ & 0.069 & 0.049 & 1.578 & & 0.182 \\
\hline$\triangle n I N F L$ & -0.184 & 0.048 & -5.536 & & 0.000 \\
\hline$\triangle F L B L$ & 0.029 & 0.015 & 1.074 & & 0.104 \\
\hline $\operatorname{Ecm}(-1)$ & -0.218 & 0.109 & -2.963 & & 0.034 \\
\hline R-Squared & 0.895 & \multicolumn{2}{|c|}{ R-Bar-Squared } & 0.796 & \\
\hline S.E. of Regression & 0.023 & \multicolumn{2}{|l|}{ F-Stat. } & $F(9,28)$ & $8.679[0.000]$ \\
\hline Residual Sum of Squares & 0.011 & \multicolumn{2}{|c|}{ DW-statistic } & 2.581 & \\
\hline Akaike Info. Criterion & 80.006 & \multicolumn{2}{|c|}{ Schwarz Bayesian Criterion } & 71.078 & \\
\hline
\end{tabular}

Note: Dependent variable: $\Delta \ln Y=\triangle \ln R G D P$.

Table 6. Economic Growth and financial reforms - ARDL-UECM model diagnostic tests

\begin{tabular}{ll}
\hline LM Test Statistics & Results \\
\hline Serial Correlation: CHSQ(1) & $2.596[0.205]$ \\
Functional Form: CHSQ(1) & $1.528[0.252]$ \\
Normality: CHSQ(2) & $1.149[0.723]$ \\
Hetroscedasticity: CHSQ(1) & $0.114[0.851]$ \\
\hline
\end{tabular}

Additionally, the regression for the underlying ARDL model fits very well at $\mathrm{R}$ square $=98.7 \%$, and it also passes all the diagnostic tests against serial correlation, functional form, normality and hetroscedasticity, as shown in Table 6. Finally, an inspection of the cumulative sum (CUSUM) and the cumulative sum of squares (CUSUMSQ) graphs (see Figures 1 and 2) from the recursive estimation of the model reveals that there is stability, and there is no systematic change detected in the coefficient at the $5 \%$ significant level over the sample period. 


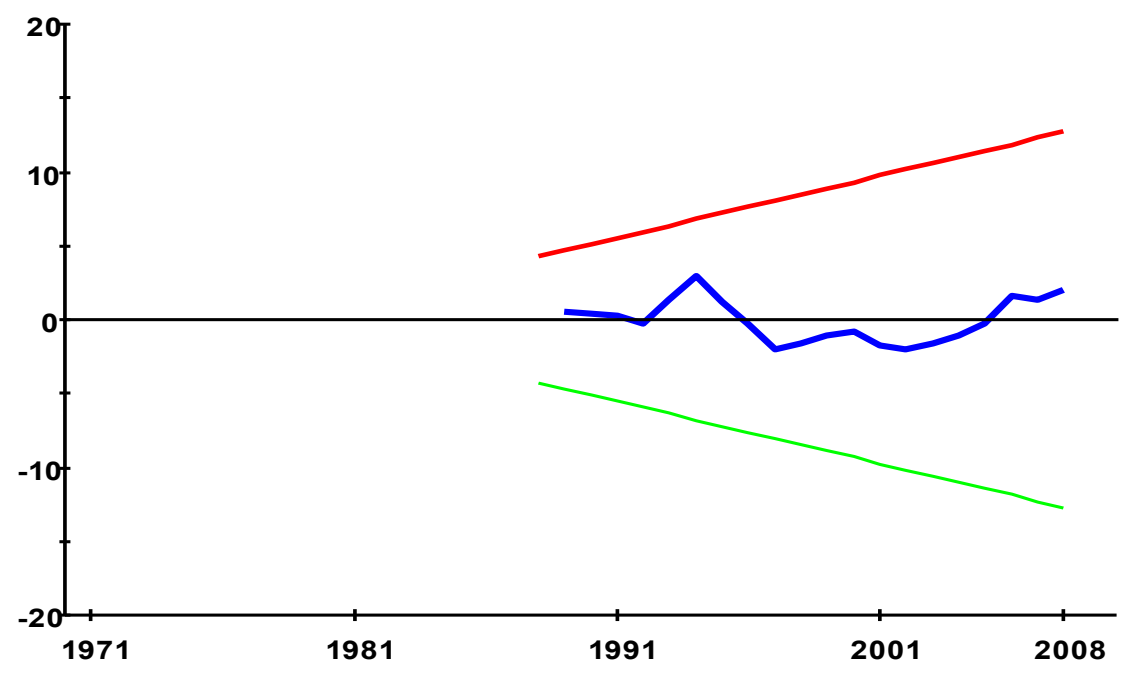

The straight lines represent critical bounds at $5 \%$ significance level

Figure 1. Economic Growth and Financial Liberalization - Plot of CUSUM for the coefficients of stability in the ECM model

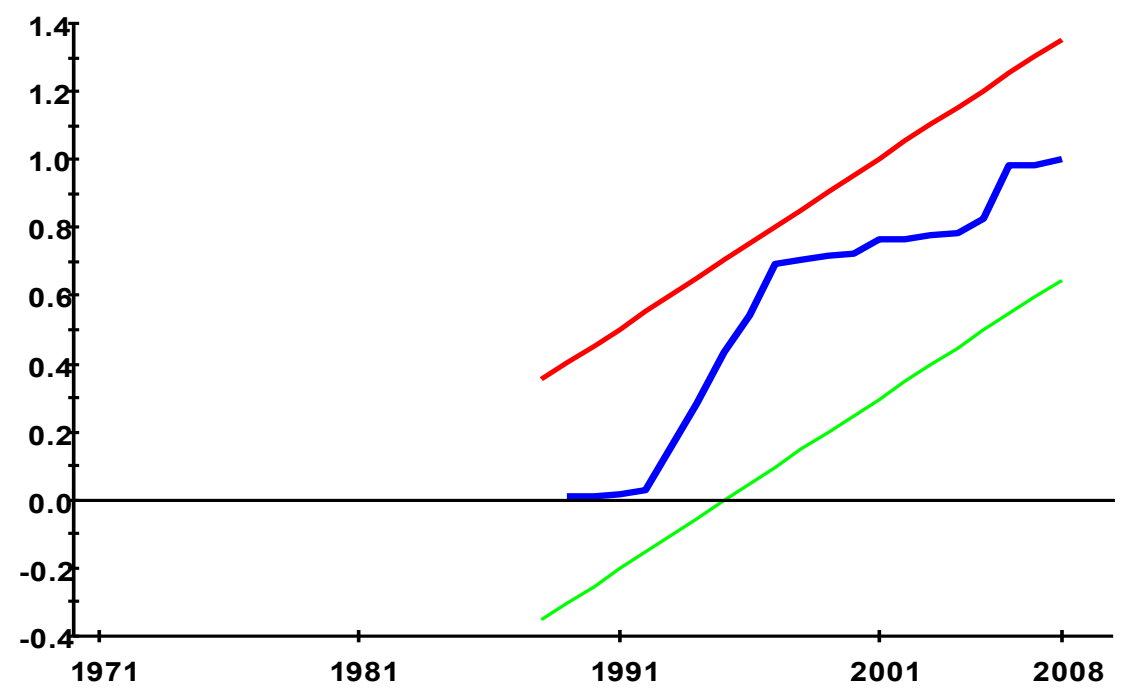

The straight lines represent critical bounds at $5 \%$ significance level

Figure 2. Economic Growth and Financial Reforms - Plot of CUSUMSQ for the coefficients of stability in the ECM model 


\section{Conclusion}

The main objective of this paper was to empirically examine and investigate the impact of financial sector reforms on sustainable economic growth in Ghana. This paper employed the ARDL bounds testing approach, the unrestricted error correction model (UECM) and the co-integration analysis popularized by Pesaran, Shin and Smith (2001) to establish the long-run relationship between the relevant time series variables. It also applied a multi-dimensional financial sector reform index constructed from a number of financial liberalization policy measures implemented as a result of the financial sector reforms in Ghana. A proviso that should be taken into consideration is that it has been recognized by many economists that co-integration techniques may not be appropriate when the sample size is too small (Narayan and Smyth, 2005).

The unit root tests employed suggest that all the variables were found to be either $\mathrm{I}(0)$ or $\mathrm{I}(1)$ stationary. Additionally, all the dependent variables were found to be co-integrated with the independent variables. This means that long-run relationships between the variables of interest were established. The empirical findings show that the impact of financial sector reforms on economic growth in Ghana is positive but insignificant in the long run, as well as in the short run. The findings therefore do not lend support to the neo-classical theory that financial liberalization leads to economic growth. A similar conclusion was reached by Hye and Wizarat (2011) in the case of Pakistan. This paper, however, finds that the increase in capital stock leads to economic growth in Ghana. To this end, we recommend that future studies apply Bartlett's test for sphericity to the financial liberalization index and obtain its Kaiser-Mayer-Olkin (KMO) coefficient to see if they reach the same conclusion.

\section{References}

Adu, G., Marbuah, G., \& Tei-Mensah, J. (2013). Financial development and economic growth in Ghana: Does the measure of financial development matter? Review of Development Finance, 3 (4), 192-203.

Aryeetey, E. (1994). Private investment under uncertainty in Ghana. World Development, 22 (8), 1211-21.

Bahmani-Oskooee, M. \& Brooks, T. J. (1999). Bilateral J-curve between U.S and her trading partners. Weltwirtschaftliches Archiv, 135 (1), 156 - 165.
Bank of Ghana. (2009). Annual Report various, Accra, Ghana

Barro, J. R., \& Sala-i-Martin, X. (2004). Economic growth ( $2^{\text {nd }}$ ed.). Cambridge, MA: The MIT Press.

Beck, T., Demirguc-Kunt, A., Levine, R., \& Maksimovic, V. (2000). Financial Structure and Economic Development: Firm, Industry and Country Evidence (Working Paper No. 2423). World Bank.

Berthélemy, J. C., Varoudakis, A. (1995). Thresholds in Financial Development and Economic Growth. The Manchester School, 63, 70-84.

Caprio, G., Honohan, P., \& Stiglitz, J. E. (Eds.). (2001). Financial Liberalization: How Far? How Fast? Cambridge, UK: Cambridge University Press.

De Gregorio, J. (1995). Financial Development and Economic Growth. World Development; 23 (3), 433-448.

Eschenbach, F. (2004). Finance and Growth: A Survey of the Theoretical and Empirical Literature (Discussion Paper No. TI 2004-039/2). Department of Economics, Erasmus Universiteit Rotterdam, and Tinbergen Institute.

Fischer, S. (2005). Globalization and Its Challenges. American Economic Review, 93 (2), 1-30.

Fry, M. J. (1995). Money, Interest and Banking in Economic Development ( $2^{\text {nd }}$ ed.). Baltimore, MD: John Hopkins University Press.

Ghana Stock Exchange. (2009). Annual Report. Accra, Ghana.

Ghana Stock Exchange. (2010). Monthly Report, August 2010. Accra, Ghana.

Hye, Q. M. A. \& Wizarat, S. (2011). Financial Liberalization and Services Sector Growth: Empirical Evidence from Pakistan. The IUP Journal of Applied Finance, 17, (2), 16-24.

Kapur, B. K. (1976). Alternative Stabilisation policies for Less Developed Countries. Journal of Political Economy, 84 (4), 777-795.

Keynes, J. M. (1936). The General Theory of Employment Interest and Money. London, UK: Macmillan.

Laeven, L. (2003). Does Financial Liberalization Reduce Financing Constraints? Financial Management, 32 (1), 5-34.

Levine, R. \& Zervos, S. (1998). Stock Markets, Banks and Economic Growth. American Economic Review, 88 (3), 537-558. 
Masih, M., Ahmad, A. H., Daud, S. N. M., \& Marzuki, A. (2008). Sovereign credit ratings and macroeconomic variables: an application of bounds testing approach to Malaysia. Journal of the Academy of Business and Economics, 8 (1), 109-119.

McKinnon, R. I. (1973). Money and capital in Economic development. Washington, DC: Brookings Institution.

McKinnon, R. I. (1989). Financial Liberalization and Economic Development: A Reassessment of Interest Rate Policies in Asia and Latin America. Oxford Review of Economic Policy, 5 (4), 29-54.

Narayan, P. K. \& Smyth, R. (2005). Trade liberalization and economic growth in Fuji: An empirical assessment using the ARDL approach. Journal of the Asian Pacific Economy, 10 (1), 96 - 115.

Pesaran, M. H., Shin, Y., \& Smith, R. J. (2001). Bounds Testing Approaches to the analysis of level relationships, Journal of Applied Econometrics, 16 (3), 289-326.

Phillips, P. C. B. \& Peron, P. (1988). Testing for a Unit Root in Time Series Regression. Biometrica, 75 (2), 335-346.

Shaw, E. S. (1973). Financial deepening in economic development. New York, NY: Oxford University Press.

Shrestha, M. B. \& Chowdhury, K. (2006). Financial liberalisation index for Nepal. International Journal of Applied Econometrics and Quantitative Studies, 3 (1), 41-54.

Sowa, N. K. \& Acquaye, I. K. (1999). Financial and Foreign Exchange Markets Liberalization in Ghana. Journal of International Development, 11 (3), 385 -409 .

Stiglitz, J. E. (1989). Financial Markets and Development. Oxford Review of Economic Policy, 5 (4), 55-68.

Taylor, L. (1983). Structuralism Macroeconomics: Applicable models for the Third World. New York, NY: Basic Books.

Tobin, J. (1965). Money and Economic Growth. Econometrical, 33 (4), 671-684.

Van Wijnbergen, S. (1983). Interest rate management in LDCs. Journal of Monetary Economics, 12 (3), 443-452.
World Bank. (2009a). World Development Report, various issues to 2009, Washington, DC.

World Bank. (2009b). African Development indicators, various issues to 2009, Washington, DC. 